\title{
Carcharocles-bitten odontocete caudal vertebrae from the Coastal Eastern United States
}

Stephen J. Godfrey, Mike Ellwood, Stephen Groff, and Michael Scott Verdin

Acta Palaeontologica Polonica 63 (3), 2018: 463-468 doi:https://doi.org/10.4202/app.00495.2018

A description and analysis is given of three Neogene odontocete caudal vertebrae that were bitten by the extinct megatooth sharks Carcharocles megalodon or Carcharocles chubutensis. The peduncular caudal vertebrae show bilateral gouge marks consistent with having been actively bitten and wedged between adjacent teeth of $C$. megalodon or $C$. chubutensis. None of the vertebrae show signs of healing. The occurrence of bite marks on distal caudals suggests active predation (vs. scavenging) in order to immobilize even relatively small prey prior to consumption.

Stephen J. Godfrey [tephen.Godfrey@calvertcountymd.gov], Department of Paleontology, Calvert Marine Museum, PO Box 97, Solomons, Maryland, 20688, USA; National Museum of Natural History, Smithsonian Institution, Washington DC, 20560, USA. Mike Ellwood [mellwood@ comcast.net], 2234 Birch Road, Port Republic, Maryland, USA. Stephen Groff [groff.sss@ verizon.net ], 11539 Tomahawk Trail, Lusby, Maryland, USA. Michael Scott Verdin [thebeanpole65@yahoo.com], 3403 Willow St., Chesapeake Beach, Maryland, USA.

This is an open-access article distributed under the terms of the Creative Commons Attribution License (for details please see creativecommons.org), which permits unrestricted use, distribution, and reproduction in any medium, provided the original author and source are credited. 